\title{
The Global Paediatric Surgery Network: A Model of Subspecialty Collaboration Within Global Surgery
}

\author{
Marilyn W. Butler $\cdot$ Doruk Ozgediz $\cdot$ Dan Poenaru • \\ Emmanuel Ameh · Safwat Andrawes · Georges Azzie • \\ Eric Borgstein · Daniel A. DeUgarte $\cdot$ Essam Elhalaby • \\ Michael E. Ganey $\cdot$ J. Ted Gerstle $\cdot$ Erik N. Hansen • \\ Afua Hesse $\cdot$ Kokila Lakhoo $\cdot$ Sanjay Krishnaswami • \\ Monica Langer - Marc Levitt • Don Meier • Ashish Minocha • \\ Benedict C. Nwomeh • Lukman O. Abdur-Rahman • \\ David Rothstein · John Sekabira
}

Published online: 25 October 2014

(C) Société Internationale de Chirurgie 2014

\section{Introduction}

Attention to surgical conditions in low- and middle-income countries (LMICs) has increased in recent years. Because half of the population in the world's poorest countries are children [1], paediatric surgical conditions compose a significant proportion of the global burden of disease

By the Global Paediatric Surgery Network Collaborative.

M. W. Butler $(\bowtie)$

Division of Pediatric Surgery, Oregon Health and Science

University (OHSU), 3181 SW Sam Jackson Park Road, Mail

Code CDW7, Portland, OR 97239, USA

e-mail: butlerm@ohsu.edu

D. Ozgediz

Yale School of Medicine, New Haven, CT, USA

e-mail: dozgediz@hotmail.com

D. Poenaru

MyungSung Medical College, Addis Ababa, Ethiopia

e-mail: dpoenaru@gmail.com

E. Ameh

Ahmadu Bello University, Zaria, Nigeria

e-mail: eaameh@yahoo.co.uk

\section{S. Andrawes}

Nairobi Hospital, Nairobi, Kenya

e-mail: safwat_andrawes@hotmail.com

\section{G. Azzie · J. T. Gerstle}

University of Toronto, Toronto, ON, Canada

e-mail: geoazz@hotmail.com

J. T. Gerstle

e-mail: ted.gerstle@sickkids.ca
(BoD), and there are critical shortages in workforce and skills to treat these diseases in LMICs. Several populationbased studies have highlighted the magnitude of the need for paediatric surgery and the limited capacity, both in human resources and in infrastructure, to tackle the problem $[2,3]$. Africa, in particular, has a grave shortage of paediatric surgeons. The number of fully trained paediatric surgeons ranges from 1 in Malawi (population 13 million) to 120 in Egypt (population of 80 million). In more than

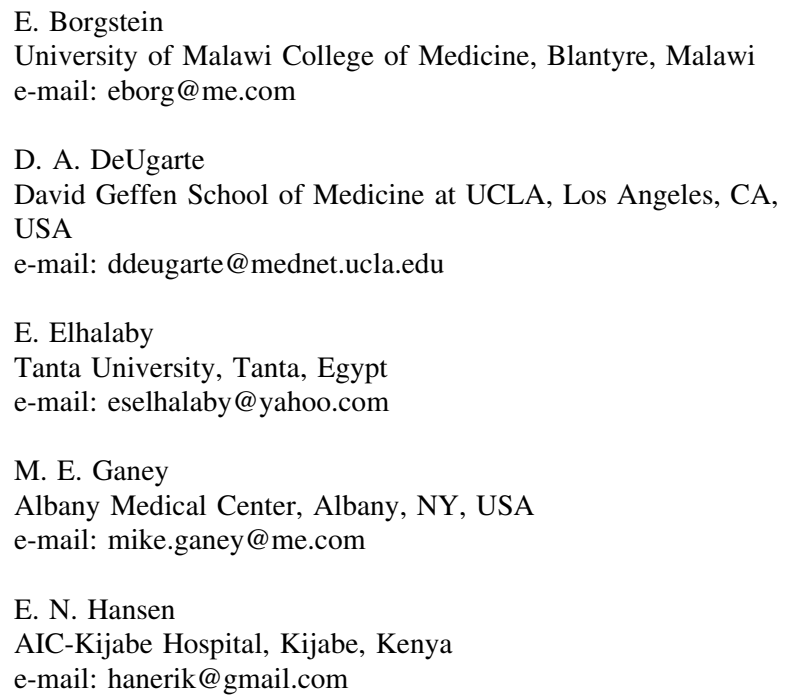

A. Hesse

University of Ghana School of Medicine and Dentistry, Accra, Ghana

e-mail: afuahesse@gmail.com 
half of African countries, no full-time paediatric surgeon is available [4, 5]. LMICs in other world regions have a similar challenge. The problem is not only limited to a poor ratio of qualified health professionals to the population, but also a significant shortage of healthcare assistants, poor primary care, delayed referral to specialists, and extensive access challenges [6]. Children in areas of conflict and disaster face exceptional challenges in having their surgical needs met [7, 8]. Despite this burden of paediatric surgical disease in LMICs, child health programs and donor funding have not prioritized surgical services, focusing instead on communicable diseases.

Surgeons in high-income countries (HICs) have taken an increased interest in opportunities for short-term volunteerism as well as long-term initiatives [9]. Trainees in HICs are increasingly interested in serving in resource-poor areas, while trainees in LMICs seek opportunities to broaden their clinical and academic skill sets through workshops and training partnerships [10-12].

The global surgery movement has emerged over the last decade with a number of strands of action-assessment of BoD, capacity and workforce measurement, practice guidelines and resource estimates, and guidelines for effective partnerships [6, 13-21]. Until now, no concerted global effort has suggested priority areas of development to improve access and outcomes in children's surgery worldwide. Furthermore, the paediatric surgery subspecialty has been slow to define priority areas, or a "roadmap" for concerted global action.

The Global Paediatric Surgery Network (GPSN) website was launched in May 2010 with the goal of serving as a clearinghouse for the volunteer work of paediatric surgeons worldwide [22, 23]. Currently, the website is translated into

\section{K. Lakhoo \\ Oxford University, Oxford, England, UK \\ e-mail: kokila.lakhoo@paediatrics.ox.ac.uk \\ S. Krishnaswami \\ Oregon Health and Science University, Portland, OR, USA \\ e-mail: krishnas@ohsu.edu}

\section{Langer}

Maine Medical Center, Portland, ME, USA

e-mail: langerm7@hotmail.com

M. Levitt · B. C. Nwomeh

Nationwide Children's Hospital, Columbus, OH, USA

e-mail: Marc.Levitt@nationwidechildrens.org

B. C. Nwomeh

e-mail: benedict.nwomeh@ nationwidechildrens.org

D. Meier

Texas Tech University Health Sciences Center El Paso, El Paso,

TX, USA

e-mail:drdonmeier@aol.com
15 languages and has been endorsed by all of the leading paediatric surgical organizations (Appendix 1).

An essential part of the GPSN is the GPSN Collaborative. This is where the GPSN extends beyond the website's rich content, bringing together an international team of globally-minded paediatric surgeons to improve paediatric surgical care in resource-poor areas. These surgeons seek to identify priority areas, to increase communication on global development goals, and to identify common interests that will serve as a platform for collaboration, all for improving access and outcomes for children's surgery where most needed.

This editorial will describe efforts of the GPSN Collaborative in the fields of networking, practice, education, research, and advocacy. While priority areas are listed separately below, there is overlap among some projects. The team's goal is to network and share expertise in developing a guide for global paediatric surgery in its efforts to improve care where most needed. Such a model may prove useful to other like-minded subspecialty movements within global surgery.

\section{Networking}

In contrast to traditional professional associations that facilitate networking within their own geographical confines, the GPSN Collaborative allows paediatric surgeons to interact, regardless of location and without the barrier of membership fees. Because providers working in resource-poor areas are well represented in the GPSN Collaborative, one of its strengths is balanced input from all stakeholders.
A. Minocha

Norwich and Norfolk University Hospital, Norwich, England,

UK

e-mail: ashish.minocha@nnuh.nhs.uk

L. O. Abdur-Rahman

College of Health Sciences, University of Ilorin, Ilorin, Nigeria

e-mail: bolarjide@yahoo.com

D. Rothstein

Women and Children's Hospital of Buffalo, Buffalo, NY, USA

e-mail: drothstein@kaleidahealth.org

J. Sekabira

Mulago Hospital, Kampala, Uganda

e-mail: jsekabira@yahoo.co.uk 
- Guidelines for international partnerships The proliferation of global health partnerships has engendered lively debates in several arenas: benefits, challenges, and ethical considerations of short-term surgical missions [24-27]; academic partnerships [17, 18, 28, 29]; research collaborations [30-32]; and best practices in skills transfer and ongoing clinical support [18, 33-37]. Some surgical subspecialty groups have adapted their own contextspecific guidelines for surgery in LMICs [38, 39], but this has not been done for paediatric surgery. The GPSN Collaborative has suggested a set of guidelines for global partnerships focused on paediatric surgical education and training in resource-poor settings (Appendix 2). Endorsement of the GPSN by the World Federation of Associations of Pediatric Surgery means the proposed guidelines will be readily offered for review and potential adoption by regional and national paediatric surgical associations across the globe. As a priority, partnerships should ensure that international training opportunities that are offered to clinicians from resource-poor areas, as well as other relationships that develop through twinning programs, do not unintentionally result in departure of staff for HICs. Practices adopted by institutions such as the Fogarty International Center at the National Institutes of Health can serve as a model for preventing "brain drain" by ensuring high rates of return of trainees to LMICs [40].

- Interdisciplinary networking An additional area of future networking activity is the creation of extended networks of paediatric health care providers in medical and surgical subspecialties, including anaesthesia, pain, nursing, and other perioperative services [41-44]. Improvements in neonatal and paediatric intensive care, as well as radiology, are particularly important in tertiary referral hospitals. To date, no such global, multidisciplinary effort has defined a coherent message for resources and needs for paediatric surgery and placed them in the context of an integrated plan for global health care for children.

- Academic networking One model for providing training in multiple specialties is an academic partnership between two institutions (for example, the Medical Education Partnership Initiative) [45]. These and other partnerships can also work with the local medical schools and Ministries of Health to help improve education, compete for research grants, and obtain foreign aid.

\section{Practice}

The Practice Group is involved in several projects aimed at helping its members and generating useful information for the specialty.
- Appropriate expertise levels and resources The GPSN Collaborative has proposed a list of common paediatric surgical conditions and their optimal sites of treatment in LMICs, categorizing paediatric surgical conditions and procedures into primary, secondary, and tertiary tiers, in order to guide provision of care in district, regional, and national referral hospitals (Appendix 3). Detailed guidelines for management at the first-referral hospital have been previously developed [46]. GPSN Collaborative members will continue to amend this list as needed and will refine the human resources, skills, infrastructure, and supplies needed at each institutional tier.

- Resource survey This study entails a broad survey of available paediatric surgical resources and facilities in resource-poor areas. Among other items, the survey investigates the human resources and infrastructure for children's surgery, and a cataloguing of the most commonly encountered paediatric surgical diseases and outcomes. A pilot paper-based version of the questionnaire, distributed among Pan African Pediatric Surgical Association (PAPSA) members at the biennial meeting in 2012, is currently under analysis. An online survey has been developed for distribution to a wider audience throughout sub-Saharan Africa, with plans to extend to other locations.

- Electronic consultant group This project would provide an outlet for surgeons in LMICs to submit problem cases electronically and get advice on management from experienced paediatric surgeons. It is also meant to serve as a forum for practitioners in resource-poor areas to share innovative low-cost approaches.

\section{Education}

The Education Group focuses on the training needs in our specialty, including the undergraduate medical, post-graduate residency, fellowship, and continuing education needs for learners and staff surgeons in LMICs. The aim is to promote collaborations across regions, while encouraging efforts promoting retention of specialists in LMICs. Some of the projects include:

- Resident/trainee exchanges between centres in LMICs and HICs While "international rotations" have become quite widespread for Western trainees, true bi-directional exchanges are rare. When organized carefully and with good input from both sides, such exchanges can be mutually beneficial. The BethanyKids of Kijabe Hospital-McGill University paediatric surgery fellowship exchange between Kenya and Canada provides such an example, where LMIC trainees are not only clinical observers, but have the opportunity for handson training [47]. 
- Continuing education of trainers Trainers in LMICs often feel isolated, overwhelmed, and frustrated, due to limited opportunities for acquisition of further knowledge and skills. The group will facilitate the continuing education of LMIC trainers through short visits, meetings, and courses. One example of this type of effort is the training of paediatric surgeons in colorectal operations. Training of general surgeons in newborn techniques and paediatric surgeons and nurses in reconstructive and post-operative management is vital to maximize these patients' quality of life. One such training program at Korle-Bu Teaching Hospital in Accra, Ghana involved several visits by visiting teams of specialists, leading Korle-Bu to become a referral centre for colorectal problems from 10 surrounding African countries, and a model for regionalization of complex care.

- Modules and case studies for common paediatric surgical conditions, geared to resource-poor settings Online clinical case scenarios for index conditions in the specialty can be easily shared and can complement onsite training efforts. A recent review of the management of colorectal conditions in resource-limited areas provides a template for the types of case discussion and clinical decision-making that might be useful [48].

- Guest teachers and external examiners The Education Group can provide guest teachers and external examiners for regional paediatric surgical accreditation examinations. The group will also link with established training colleges and regional specialty boards to assist with curriculum review and program development if needed.

- Other priority areas of support for existing training programs Based on local needs and resources, the group will assist training programs in LMICs. A first step underway is identification of existing training programs and their needs. This may also include assistance with the delivery of undergraduate topics relevant to paediatric surgical diseases

- Web meetings Web meetings are a high-impact, costeffective teaching method that can be accessed from any personal computer with online access. A good example is the free educational web meeting organized weekly by the Red Cross War Memorial Children's Hospital in Cape Town, South Africa [49]. Telemedicine, with electronic educational modules, as reported from Durban, South Africa also provides a valuable resource [50].

\section{Research}

The aim of the Research Group is to generate local and global knowledge based on the needs of paediatric surgeons practicing primarily in resource-poor settings. The following are projects currently being undertaken:

- Disparities in paediatric surgical outcomes between LMICs and HICs A review is underway of the paediatric surgery outcomes literature in LMICs, with comparison of outcomes to those in HICs.

- Burden of Disease (BoD) concepts applied to paediatric surgery A recent review has summarized BoD principles and applications in our specialty, including concepts such as surgical backlog and measurement of disability incurred by delays in care [51]. Disability weights for paediatric surgical conditions are required for estimating disability-adjusted life years (DALYs), and are currently only available for a minority of the common paediatric surgical conditions. Recent work has tried to provide accurate estimates for a wider range of conditions [52].

- Clinical paediatric surgical databases and trauma registries These databases can facilitate prospective clinical data collection by any site, for the purpose of identifying priorities, monitoring and evaluating programs, designing interventions, and other research and quality improvement activities.

- Estimation of paediatric surgical conditions and workload provided by major non-governmental organizations operating in civil conflict and natural disaster zones A study is currently underway to characterize the paediatric surgery experience of Médecins sans Frontières, and the project may be extended to other providers. Further research could help establish minimal standards for paediatric surgical capacity and response to natural disasters [53].

\section{Advocacy}

Paediatric surgeons working in resource-poor areas bear witness directly to the harms of delayed or absent surgical care on children, families, and communities; as such, they are uniquely positioned as surgical child health advocates. The Advocacy Group will take global paediatric surgical statistics and BoD data (as obtained above) as well as their direct clinical service experience and translate them into marketable messages for the purpose of advocacy, fundraising, and lobbying.

\section{Conclusion}

The GPSN Collaborative was created to foster a global, united effort for improving paediatric surgery access and outcomes in LMICs. Its focus areas and activities aim to 
build on the work of national and regional paediatric surgical organizations, as well as existing individual initiatives and partnerships. Global representation in the GPSN Collaborative facilitates joint development and broad acceptance of initiatives for resource-poor practice settings. While membership is diverse, some regions are over-represented (USA, Europe, Sub-Saharan Africa) compared with others (South America, the Middle East, sub-continent Asia, and Southeast Asia), limiting the generalizability of this model. Outreach and linkages with other regions is underway and will be essential to further validate the feasibility of this approach. Success will be measured by deliverables in each of the priority areas of networking, practice, education, research, and advocacy. This model may prove useful to surgical subspecialty organizations seeking to develop a joint effort for improving surgical care worldwide.

Acknowledgments The authors would like to acknowledge the following for their interest and involvement in various projects of the GPSN Collaborative: Niye Ade Ajayi, Petronilla Ngiloi, Stephen Bickler, and Katarina Biller.

Appendix 1: Paediatric surgical organizations that have endorsed the Global Paediatric Surgery Network

1. World Federation of Associations of Pediatric Surgeons

2. Pacific Association of Pediatric Surgeons

3. Canadian Association of Paediatric Surgeons

4. International Pediatric Endosurgery Group

5. European Pediatric Surgeons' Association

6. British Association of Paediatric Surgeons

7. American Pediatric Surgical Association

8. Australian and New Zealand Association of Paediatric Surgeons

9. Pan African Pediatric Surgical Association

Appendix 2: Suggested guidelines for partnerships fostering paediatric surgical education and training in resource-poor settings (2013)

Partners may be private organizations, hospitals, or academic institutions. Ideally, core values should include

1. Education, professional development, and patient safety.

2. Ongoing evaluation of intervention effectiveness and quality of care.
3. Explicit acknowledgement that visiting and host teams can each learn from one another.

LMIC hosts and international partners should participate in a needs assessment where strengths and weaknesses, as well as available resources can be discussed

4. Needs assessments may be performed through group discussions, individual meetings with stakeholders, surveys, or other means.

5. Needs may require prioritization, and goal-setting with specific short- and long-term objectives.

6. Discussion of resources should include ways to maximize local resources and identify ongoing partnerships and initiatives to minimize duplication and maximize collaboration among international partners.

7. A mutually drafted memorandum of understanding (MOU) outlining shared goals and objectives that are regularly reviewed may facilitate the partnership.

To maximize chances of success

8. Tasks should be realistic and feasible within the framework of the host institution.

9. The collaboration and project should be endorsed by the authorities of the host institution (e.g. hospital and university management).

10. Partners should agree to become equally involved in the design and delivery of the educational and continuing professional development curriculum, and trainees should be involved in this process.

11. Host surgical faculty and trainees should negotiate a realistic time frame to be released from clinical duties to participate in educational and continuing professional development activities, so that the clinical environment is not depleted of medical staff and patient care is not compromised. The goal should be minimal disruption of ongoing daily work by host physicians, nurses, and other staff who might otherwise abandon scheduled tasks in order to accommodate visiting teams.

12. The focus of any direct clinical care should be to maximize opportunities for education and continuing professional development to the host health care providers, including trainees and ancillary staff.

13. All partners should seek to speak a common language or have translators available to facilitate didactics and one-on-one teaching.

14. Whenever research is being contemplated, a research agenda should be developed, prioritized, and 
collaborative research should translate to jointauthored publications and presentations.

15. Evaluation tools to assess success of skills transfer and capacity development may be developed.

16. The potential for "brain drain" should be acknowledged, and all efforts should be made to ensure training of surgeons who are committed to continue practicing in the host country.

\section{Logistical considerations}

17. Logistical issues such as medical licencing and physical safety of all staff should be discussed and arranged in the planning process.

18. Members of international partner groups new to the resource-poor setting should be oriented to clinical, ethical, and socio-cultural challenges of the practice, educational, and professional environment prior to travel.

19. For partnerships that include a focus on short-term trips, criteria should be established for case selection and follow-up, inclusive of safe anaesthesia and analgesia.

20. Data and information storage may need to be developed in order to enable adequate evaluations and assessment of the processes and for clinical audit purposes.

21. Both teams should seek techniques that are suitable for the local environment, depending on the resources available and the pattern of existing local diseases.

Appendix 3 Capacity guidelines for selected paediatric surgical conditions at various levels of the health system (2013)

\begin{tabular}{lllll}
\hline & $\begin{array}{l}\text { Village } \\
\text { health } \\
\text { center }\end{array}$ & $\begin{array}{l}\text { District } \\
\text { hospital }\end{array}$ & $\begin{array}{l}\text { Regional } \\
\text { hospital }\end{array}$ & $\begin{array}{l}\text { Tertiary } \\
\text { referral } \\
\text { hospital }\end{array}$ \\
\hline $\begin{array}{l}\text { Airway management, fluid } \\
\text { replacement, bleeding } \\
\text { control, antibiotic therapy }\end{array}$ & $\times$ & $\times$ & $\times$ \\
$\begin{array}{l}\text { Blood transfusion } \\
\begin{array}{l}\text { Identification and referral of } \\
\text { visible congenital anomalies }\end{array}\end{array}$ & $\times$ & $\times$ & $\times$ & $\times$ \\
$\begin{array}{l}\text { Paediatric appendicitis } \\
\text { Intussusception (hydrostatic } \\
\text { reduction) }\end{array}$ & & $\times$ & $\times$ & $\times$ \\
$\begin{array}{l}\text { Initial trauma care } \\
(\text { stabilization) }\end{array}$ & $\times$ & $\times$ & $\times$ \\
$\begin{array}{l}\text { Definitive trauma care (solid } \\
\text { organ injury) }\end{array}$ & & $\times$ & $\times$ & $\times$ \\
\hline
\end{tabular}

\begin{tabular}{|c|c|c|c|c|}
\hline & $\begin{array}{l}\text { Village } \\
\text { health } \\
\text { center }\end{array}$ & $\begin{array}{l}\text { District } \\
\text { hospital }\end{array}$ & $\begin{array}{l}\text { Regional } \\
\text { hospital }\end{array}$ & $\begin{array}{l}\text { Tertiary } \\
\text { referral } \\
\text { hospital }\end{array}$ \\
\hline $\begin{array}{l}\text { Soft tissue infections (simple) } \\
\text { and wound care }\end{array}$ & $x$ & $x$ & $x$ & $x$ \\
\hline $\begin{array}{l}\text { Soft tissue infections } \\
\text { (complex) }\end{array}$ & & $x$ & $x$ & $x$ \\
\hline $\begin{array}{l}\text { Abdominal masses (including } \\
\text { Wilms Tumour) }\end{array}$ & & & & $x$ \\
\hline Intestinal obstruction & & $x$ & $x$ & $x$ \\
\hline $\begin{array}{l}\text { Peritonitis (secondary to any } \\
\text { cause including perforated } \\
\text { appendicitis and typhoid } \\
\text { perforation) }\end{array}$ & & & $x$ & $x$ \\
\hline $\begin{array}{l}\text { Paediatric hernia (over } 1 \text { year } \\
\text { old) }\end{array}$ & & $x$ & $\times$ & $x$ \\
\hline $\begin{array}{l}\text { Paediatric hernia (infant less } \\
\text { than } 1 \text { year old) }\end{array}$ & & & $\times$ & $x$ \\
\hline Umbilical hernia & & $x$ & $x$ & $x$ \\
\hline Pyloric stenosis & & & $x$ & $x$ \\
\hline $\begin{array}{l}\text { Colostomy (formation or } \\
\text { closure) }\end{array}$ & & $x$ & $x$ & $x$ \\
\hline $\begin{array}{l}\text { Neonatal bowel obstruction } \\
\text { (atresia/stenosis) }\end{array}$ & & & & $x$ \\
\hline Malrotation $^{\mathrm{a}}$ & & & & $x$ \\
\hline Necrotizing enterocolitis & & & & $x$ \\
\hline $\begin{array}{l}\text { Tracheo-oesophageal fistula } \\
\text { repair }\end{array}$ & & & & $x$ \\
\hline $\begin{array}{l}\text { Anorectal malformation/ } \\
\text { Hirschsprung Disease (first } \\
\text { stage; often colostomy) }\end{array}$ & & $x$ & $\times$ & $x$ \\
\hline $\begin{array}{l}\text { Anorectal malformation/ } \\
\text { Hirschsprung disease } \\
\text { (definitive treatment) }\end{array}$ & & & $x$ & $x$ \\
\hline Abdominal wall defects & & & $\times$ & $x$ \\
\hline Bladder exstrophy & & & & $x$ \\
\hline Undescended testicles & & & $x$ & $x$ \\
\hline Hypospadias & & & & $x$ \\
\hline Bladder stone removal & & $x$ & $x$ & $x$ \\
\hline $\begin{array}{l}\text { Posterior urethral valves } \\
\text { treatment }\end{array}$ & & & $x$ & $x$ \\
\hline
\end{tabular}

${ }^{\text {a }}$ Unstable patients with life-threatening diseases might need to be treated initially at District or Regional Hospitals

Additional notes

(1) Please see reference for definitions of various levels of the health system [54]

(2) The District and Regional Hospital must be adequately equipped with the minimum equipment requirements as recommended by the World Health Organization (WHO) and must also have suitable fluids and medications as identified on the minimum drugs lists

\section{References}

1. Maternal, newborn, and child health scorecards (2013). http:// www.who.int/maternal_child_adolescent/documents/countries/ indicators/en/

2. Kushner AL, Groen RS, Kamara TB, Dixon-Cole R, Daoh KS, Kingham TP et al (2012) Assessment of pediatric surgery 
capacity at government hospitals in Sierra Leone. World J Surg 36(11):2554-2558. doi:10.1007/s00268-012-1737-3

3. Petroze RT, Groen RS, Niyonkuru F, Mallory M, Ntaganda E, Joharifard S et al (2013) Estimating operative disease prevalence in a low-income country: results of a nationwide population survey in Rwanda. Surgery 153(4):457-464

4. Elhalaby EA, Uba FA, Borgstein ES, Rode H, Millar AJ (2012) Training and practice of pediatric surgery in Africa: past, present, and future. Semin Pediatr Surg 21(2):103-110

5. Chirdan LB, Ameh EA, Abantanga FA, Sidler D, Elhalaby EA (2010) Challenges of training and delivery of pediatric surgical services in Africa. J Pediatr Surg 45(3):610-618

6. Grimes CE, Bowman KG, Dodgion CM, Lavy CB (2011) Systematic review of barriers to surgical care in low-income and middle-income countries. World J Surg 35(5):941-950. doi:10. 1007/s00268-011-1010-1

7. Albertyn R, Bickler SW, van As AB, Millar AJ, Rode H (2003) The effects of war on children in Africa. Pediatr Surg Int 19(4):227-232

8. Wu VK, Poenaru D (2013) Burden of surgically correctable disabilities among children in the Dadaab Refugee Camp. World J Surg 37(7):1536-1543. doi:10.1007/s00268-012-1899-z

9. Butler MW, Krishnaswami S, Rothstein DH, Cusick RA (2011) Interest in international surgical volunteerism: results of a survey of members of the American Pediatric Surgical Association. J Pediatr Surg 46(12):2244-2249

10. Powell AC, Mueller C, Kingham P, Berman R, Pachter HL, Hopkins MA (2007) International experience, electives, and volunteerism in surgical training: a survey of resident interest. J Am Coll Surg 205(1):162-168

11. Barton A, Williams D, Beveridge M (2008) A survey of Canadian general surgery residents' interest in international surgery. Can J Surg 51(2):125-129

12. Ozgediz D, Roayaie K, Debas H, Schecter W, Farmer D (2005) Surgery in developing countries: essential training in residency. Arch Surg 140(8):795-800

13. Mock C, Cherian M, Juillard C, Donkor P, Bickler S, Jamison D et al (2010) Developing priorities for addressing surgical conditions globally: furthering the link between surgery and public health policy. World J Surg 34(3):381-385. doi:10.1007/s00268009-0263-4

14. Lavy C, Sauven K, Mkandawire N, Charian M, Gosselin R, Ndihokubwayo JB et al (2011) State of surgery in tropical Africa: a review. World J Surg 35(2):262-271. doi:10.1007/s00268-0100885-6

15. Kushner AL, Cherian MN, Noel L, Spiegel DA, Groth S, Etienne C (2010) Addressing the Millenium Development Goals from a surgical perspective: essential surgery and anesthesia in 8 lowand middle-income countries. Arch Surg 145(2):154-159

16. Petroze RT, Nzayisenga A, Rusanganwa V, Ntakiyiruta G, Calland JF (2012) Comprehensive national analysis of emergency and essential surgical capacity in Rwanda. Br J Surg 99(3):436-443

17. Riviello R, Ozgediz D, Hsia RY, Azzie G, Newton M, Tarpley J (2010) Role of collaborative academic partnerships in surgical training, education, and provision. World J Surg 34(3):459-465. doi:10.1007/s00268-009-0360-4

18. Grimes CE, Maraka J, Kingsnorth AN, Darko R, Samkange CA, Lane RH (2013) Guidelines for surgeons on establishing projects in low-income countries. World J Surg 37(6):1203-1207. doi:10. 1007/s00268-013-1999-4

19. Welling DR, Ryan JM, Burris DG, Rich NM (2010) Seven sins of humanitarian medicine. World J Surg 34(3):466-470. doi:10. 1007/s00268-009-0373-z

20. Groen RS, Samai M, Stewart KA, Cassidy LD, Kamara TB, Yambasu SE et al (2012) Untreated surgical conditions in Sierra
Leone: a cluster randomised, cross-sectional, countrywide survey. Lancet 380(9847):1082-1087

21. Groen RS, Samai M, Petroze RT, Kamara TB, Cassidy LD, Joharifard S et al (2013) Household survey in Sierra Leone reveals high prevalence of surgical conditions in children. World J Surg 37(6):1220-1226. doi:10.1007/s00268-013-1996-7

22. Global Paediatric Surgery Network (2013). http://www.glo balpaediatricsurgery.org

23. Butler MW, Krishnaswami S, Minocha A (2012) The global paediatric surgery network: early measures of interest in the website. Eur J Pediatr Surg 22(1):80-84

24. Casey KM (2007) The global impact of surgical volunteerism. Surg Clin North Am 87(4):949-960 ix

25. Isaacson G, Drum ET, Cohen MS (2010) Surgical missions to developing countries: ethical conflicts. Otolaryngol Head Neck Surg 143(4):476-479

26. Dupuis CC (2004) Humanitarian missions in the third world: a polite dissent. Plast Reconstr Surg 113(1):433-435

27. Martiniuk AL, Manouchehrian M, Negin JA, Zwi AB (2012) Brain Gains: a literature review of medical missions to low and middle-income countries. BMC Health Serv Res 12:134

28. Axt J, Nthumba PM, Mwanzia K, Hansen E, Tarpley MJ, Krishnaswami S et al (2013) Commentary: the role of global surgery electives during residency training: relevance, realities, and regulations. Surgery 153(3):327-332

29. Henry JA, Groen RS, Price RR, Nwomeh BC, Kingham TP, Hardy MA et al (2013) The benefits of international rotations to resource-limited settings for U.S. surgery residents. Surgery 153(4):445-454

30. Crump J, Sugarman J (2010) Working group on ethics guidelines for global health training. Am J Trop Med Hyg 83:1178-1182

31. Holm J, Malete L (2010) Nine problems that hinder partnerships in Africa. Chronicle of Higher Education. http://chronicle.com/ article/Nine-Problems-That-Hinder-P/65892/

32. Laabes EP, Desai R, Zawedde SM, Glew RH (2011) How much longer will Africa have to depend on western nations for support of its capacity-building efforts for biomedical research? Trop Med Int Health 16(3):258-262

33. Calisti A, Belay K, Mazzoni G, Fiocca G, Retrosi G, Olivieri C (2011) Promoting major pediatric surgical care in a low-income country: a 4-year experience in Eritrea. World J Surg 35(4):760-766. doi:10.1007/s00268-011-0992-z

34. Duenas VJ, Hahn EJ, Aryan HE, Levy MV, Jandial R (2012) Targeted neurosurgical outreach: 5-year follow-up of operative skill transfer and sustainable care in Lima, Peru. Childs Nerv syst 28(8):1227-1231

35. Meier D (2010) Opportunities and improvisations: a pediatric surgeon's suggestions for successful short-term surgical volunteer work in resource-poor areas. World J Surg 34(5):941-946. doi:10.1007/s00268-010-0454-z

36. Warf BC (2009) Neurosurgical humanitarian aid. J Neurosurg Pediatr 4(1):1-2 discussion -3

37. Loisance DY (2012) Training young cardiac surgeons in developing countries. Asian Cardiovasc Thorac Ann 20(4):384-386

38. Schneider WJ, Politis GD, Gosain AK, Migliori MR, Cullington JR, Peterson EL et al (2011) Volunteers in plastic surgery guidelines for providing surgical care for children in the less developed world. Plast Reconstr Surg 127(6):2477-2486

39. Schneider WJ, Migliori MR, Gosain AK, Gregory G, Flick R (2011) Volunteers in plastic surgery guidelines for providing surgical care for children in the less developed world: part II. Ethical considerations. Plast Reconstr Surg 128(3):216e-222e

40. Kupfer L, Hofman K, Jarawan R, McDermott J, Bridbord K (2004) Roundtable. Strategies to discourage brain drain. Bull World Health Organ 82(8):616-619 discussion 9-23 
41. Rao SG (2007) Pediatric cardiac surgery in developing countries. Pediatr Cardiol 28(2):144-148

42. Warf BC (2011) Hydrocephalus associated with neural tube defects: characteristics, management, and outcome in sub-Saharan Africa. Childs Nerv Syst 27(10):1589-1594

43. Ouro-Bang'na Maman AF, Kabore RA, Zoumenou E, Gnassingbe K, Chobli M (2009) Anesthesia for children in Sub-Saharan Africa-a description of settings, common presenting conditions, techniques and outcomes. Paediatr Anaesth 19(1):5-11

44. Atijosan O, Simms V, Kuper H, Rischewski D, Lavy C (2009) The orthopaedic needs of children in Rwanda: results from a national survey and orthopaedic service implications. J Pediatr Orthop 29(8):948-951

45. Medical Education Partnership Initiative (2014). http://www.fic. nih.gov/programs/Pages/medical-education-africa.aspx

46. Bickler S, Ameh E (2011) Surgical care for children: a guide for primary referral hospitals. MacMillan, New York

47. Ganey M, Baird R, Poenaru D (eds) (2012) Partnership through fellowship: the Bethany Kids-McGill University pediatric surgery fellowship exchange. Pan-African Paediatric Surgical Association, Capetown

48. Poenaru D, Borgstein E, Numanoglu A, Azzie G (2010) Caring for children with colorectal disease in the context of limited resources. Semin Pediatr Surg 19(2):118-127
49. Pediatric surgical skills training center (2013). http://www.surgi calskills.co.za

50. Hadley GP, Mars M (2011) e-Education in paediatric surgery: a role for recorded seminars in areas of low bandwidth in subSaharan Africa. Pediatr Surg Int 27(4):407-410

51. Ozgediz D, Poenaru D (2012) The burden of pediatric surgical conditions in low and middle income countries: a call to action. J Pediatr Surg 47(12):2305-2311

52. Poenaru D, Pemberton J, Frankfurter C, Cameron B (2013) Establishing disability weights for congenital paediatric surgical disease: a cross-sectional, multi-model study. Lancet 381(Supplement 2):S115

53. Rothstein DH (2013) Pediatric care in disasters. Pediatrics 132(4):602-605

54. Hensher M, Price M, Adomakoh S (2006) Referral Hospitals. In: Jamison DT, Breman JG, Measham AR, Alleyne G, Claeson M, Evans DB et al (eds) Disease control priorities in developing countries. The International Bank for Reconstruction and Development/The World Bank Group, Washington (DC) 